\title{
Seasonal co-occurrence of sea turtles, bottlenose dolphins, and commercial gill nets in southern Pamlico and northern Core Sounds, and adjacent coastal waters of North Carolina, USA
}

\author{
April Goodman Hall ${ }^{1, *}$, Joanne Braun McNeill ${ }^{1}$, Paul B. Conn ${ }^{1,2}$, Erik Davenport ${ }^{3}$, \\ Aleta A. Hohn ${ }^{1}$ \\ ${ }^{1}$ National Marine Fisheries Service, Southeast Fisheries Science Center, Beaufort Laboratory, 101 Pivers Island Road, \\ Beaufort, North Carolina 28516, USA \\ ${ }^{2}$ National Marine Fisheries Service, Alaska Fisheries Science Center, National Marine Mammal Laboratory, \\ 7600 Sand Point Way NE, Seattle, Washington 98115, USA \\ ${ }^{3}$ National Ocean Service, National Center for Coastal Ocean Science, Center for Coastal Monitoring and Assessment, \\ 1305 East-West Hwy, Silver Spring, Maryland 20910, USA
}

\begin{abstract}
We assessed the seasonal co-occurrence of sea turtles and bottlenose dolphins Tursiops truncatus with commercial gill nets in southern Pamlico and northern Core Sounds, and adjacent coastal waters of North Carolina, USA, from 41 aerial surveys conducted from 2004 to 2006. Generalized linear models were used to examine the influence of several variables (month, year, habitat type [coastal and estuarine], sea surface temperature, and visibility conditions) on counts of turtles, dolphins, and gill nets. A total of 86 turtles, 1559 dolphins, and 378 gill nets were observed. Predicted counts of turtles and dolphins were highest concurrent with gill nets in spring and autumn in both habitats. Observed spatial overlap of dolphins and gill nets occurred throughout the estuary from spring to autumn, but was limited mainly to the eastern portion of the estuary in winter; spatial overlap of turtles and gill nets occurred predominantly in the eastern portion of the estuary in spring and autumn, and throughout the estuary in summer. During all seasons, dolphins ( 57 to $75 \%$ ) and gill nets ( 80 to $88 \%$ ) were predominantly observed in shallow $(<2 \mathrm{~m})$ waters of the estuary; turtles $(75 \%)$ were seen most often in shallow estuarine waters in spring. Along the coast, observed spatial overlap of turtles and dolphins with gill nets occurred most often in the region extending from Cape Hatteras south to Ocracoke. These findings improve our knowledge of habitat use by these species, and may also help manage interactions.
\end{abstract}

KEY WORDS: Bottlenose dolphin - Tursiops truncatus - Bycatch · Gill net - North Carolina · Sea turtle

\section{INTRODUCTION}

The unintentional capture of non-target species in fishing gear (bycatch) is a global issue influencing the conservation of marine species (Read et al. 2006, Read 2008, Moore et al. 2009, Finkbeiner et al. 2011). Species that mature late and have low reproductive rates, such as marine mammals and sea turtles, are particularly susceptible to anthropogenic mortality (Heppell et al. 2000, Lewison et al. 2004). Within North Carolina's marine waters, high levels of sea turtle and bottlenose dolphin Tursiops truncatus interactions with commercial gill nets have resulted in seasonal and/or area closures and gear restrictions 
(NMFS 1999, 2002a,b, 2006). These measures have generally been considered successful in some areas and during certain times of the year (Murray 2009, McClellan et al. 2011, Daniel 2012, and see Byrd et al. 2011 for a summary); however, information is needed regarding the seasonal co-occurrence of turtles and dolphins with North Carolina's commercial gill-net fisheries in other locations and among other seasons to determine risks due to co-occurrence, and to help direct efforts to measure and mitigate these risks.

North Carolina's marine waters serve as important developmental and foraging habitat for protected sea turtles and bottlenose dolphins (Epperly et al. 2007, Waring et al. 2011). Loggerhead turtles Caretta caretta, green turtles Chelonia mydas, and Kemp's ridley turtles Lepidochelys kempii repopulate the estuarine and nearshore coastal waters in spring (March to May), as water temperature increases, and emigrate to warmer coastal waters in late autumnearly winter (November to December) (Shoop \& Kenney 1992, Epperly et al. 1995a,b, 2007, Keinath et al. 1996, Mansfield et al. 2009). Leatherback turtles Dermochelys coriacea occasionally enter the estuary (Epperly et al. 1995a,b), and are common in nearshore coastal waters in spring and summer (Lee \& Palmer 1981, Shoop \& Kenney 1992, Epperly et al. 1995a,b, Grant et al. 1996). The estuarine waters are primarily utilized by juvenile sea turtles, while the coastal region is inhabited by juveniles and adults (Epperly et al. 1995a,b). Bottlenose dolphins are present year-round in the coastal and estuarine waters, although densities vary seasonally based on movements of migratory and resident stocks (Read et al. 2003, Torres et al. 2005, Waring et al. 2011). For instance, 2 migratory stocks occur seasonally in coastal waters: the Northern Migratory Coastal Stock (NMCS) and Southern Migratory Coastal Stock (SMCS). These stocks primarily occur in coastal waters, but occasionally enter the estuary (Waring et al. 2011). Conversely, the 2 estuarine stocks, the Northern North Carolina Estuarine System Stock (NNCES) and Southern North Carolina Estuarine System Stock (SNCES), primarily occur in the estuary, but occasionally inhabit the coastal waters.

North Carolina's commercial gill-net fisheries are highly dynamic, due in part to the seasonal influx of migrant fish into the region (Steve et al. 2001). The estuarine and coastal gill-net fisheries operate yearround, and target a variety of finfish species using an assortment of gear configurations (e.g. small or large mesh, run-around nets, set nets, drift nets) (Steve et al. 2001). Fishing effort depends on target species and varies among ports; however, peak activity usually occurs from mid-autumn to mid-spring in nearshore coastal waters, and in spring, late summer, and autumn in the estuary (Wilson 1997, Steve et al. 2001).

Within Pamlico Sound, the large-mesh $(\geq 5.5$ inch $[\geq 14 \mathrm{~cm}] \mathrm{mesh}$ ) sink gill-net fishery for southern flounder Paralichthys lethostigma operates primarily during autumn, and is one of the most economically valuable finfish fisheries in North Carolina (NCDMF 2005). Frequent interactions between sea turtles and gill nets used in this fishery resulted in the permanent closure of the deep-water ( 3 to $6 \mathrm{~m}$ ) portion of the fishery in 2002 (NMFS 2002b, see Byrd et al. 2011 for a detailed description). The shallow-water (1 to $3 \mathrm{~m}$ ) portion of the fishery still operates in designated restricted areas in Pamlico Sound. Management measures restricting the autumn large-mesh gill-net fishery for southern flounder to designated shallowwater restricted areas within Pamlico Sound have generally been considered successful in reducing sea turtle bycatch rates, particularly for loggerhead and Kemp's ridley turtles (Daniel 2012).

Areas with a high potential for sea turtle bycatch in large-mesh gill nets have also been identified outside of Pamlico Sound, and during seasons other than autumn (see Byrd et al. 2011, Daniel 2012, NMFS Southeast Fisheries Science Center [SEFSC], Beaufort, NC, unpubl. alternative platform study). For instance, in 2009, NMFS observers documented a high number of sea turtle interactions with largemesh gill nets in Core Sound and adjacent water bodies beginning in late June (NMFS SEFSC, Beaufort, NC, unpubl. alternative platform study). Since 2010, the North Carolina Division of Marine Fisheries (NCDMF) has been in the process of applying for a statewide Incidental Take Permit (ITP) from the National Marine Fisheries Service (NMFS) under Section 10 of the Endangered Species Act to cover incidental takes of sea turtles by gill nets within North Carolina's estuarine waters. In the interim, additional large-mesh gill-net restrictions and modifications have been established, and the NCDMF has been required to provide observer coverage on $7 \%$ of the large-mesh gill-net fishing trips in the estuarine waters (Duke Law School 2010), which would allow for estimates of turtle bycatch.

Information related to the spatio-temporal overlap of estuarine bottlenose-dolphin stocks and fisheries is especially important because bycatch poses greater risks to these stocks due to their small population sizes (Barlow et al. 1995, Waring et al. 2011). North Carolina's estuarine gill-net fishery is classi- 
fied as a Category II fishery (termed the NC inshore gill-net fishery) under the Marine Mammal Protection Act, indicating occasional incidental mortality or serious injury of marine mammals (NMFS 2012). Because there are no bycatch estimates from observer data (Waring et al. 2011), evidence for bycatch in the estuarine gill-net fishery is only known from stranded dolphins with entanglement lesions (Read \& Murray 2000) indicative of gill nets (NMFS SEFSC, Beaufort, NC, unpubl. data). Beginning in 2010, the NMFS Northeast Fishery Observer Program (NEFOP) has observed the gill-net fishery in Pamlico Sound to collect dolphin bycatch data (Keystone Center 2012, NMFS Northeast Fisheries Science Center [NEFSC], Woods Hole, MA, unpubl. data).

In the coastal waters, a number of gill-net regulations (e.g. seasonal and/or area closures, commercial fishery quotas, and fishing or gear restrictions) have been implemented to reduce interactions with sea turtles (NMFS 2002a) and bottlenose dolphins (NMFS 2006) or to manage fish stocks (ASMFC 2002, 2008). Additionally, observer coverage of gill-net fisheries in coastal waters has allowed for bycatch estimates of sea turtles (Murray 2009) and bottlenose dolphins (Waring et al. 2011).

Beginning in 2004, we were requested by Marine Corps Air Station (MCAS) Cherry Point to conduct aerial surveys to examine the seasonal occurrence of sea turtles and bottlenose dolphins in relation to the MCAS' restricted airspace R-5306 A, which encompasses portions of Core and Pamlico Sounds, North Carolina. The surveys were also extended into the nearshore coastal waters adjacent to R-5306 A to examine the seasonal occurrence of turtles and dolphins in this region as well. This opportunity provided us access to areas that are normally restricted (such as the 2 bombing targets in western Pamlico Sound), and thus, where less is known of habitat use by turtles and dolphins. Additionally, it allowed us the unique opportunity to survey portions of the coastal and estuarine waters concurrently on a year-round basis, and to examine turtle and dolphin distribution in relation to other activities, such as commercial fishing. In this paper, we present the results of this study with the specific objective of aiding conservation managers with the identification of locations and times when sea turtles and bottlenose dolphins may be more likely to co-occur with commercial gill nets in North Carolina's estuarine and nearshore coastal waters. Such information may help direct efforts to measure (i.e. observer coverage) and mitigate bycatch, and it also increases our understanding of habitat use by these species. In particular, our aerial observations were used to (1) describe the seasonal distribution of turtles, dolphins, and gill nets within our survey area, (2) examine this distribution relative to water depth in the estuary, and (3) examine the autumn distribution of turtles in southern Pamlico Sound relative to the designated shallow-water restricted areas where large-mesh gillnetting is allowed. Generalized linear models (GLMs) were then used to explore the effect of month, sea surface temperature (SST), year, and habitat type (coastal or estuarine) on counts of dolphins, turtles, and gill nets, while simultaneously accounting for possible confounding environmental factors (e.g. sea state, turbidity, weather, and glare) encountered during surveys.

\section{MATERIALS AND METHODS}

\section{Study area}

The study site included southern Pamlico and northern Core Sounds (approximately $2221 \mathrm{~km}^{2}$ ), and nearshore coastal waters from Cape Hatteras to just south of Drum Inlet, extending $1.6 \mathrm{~km}$ from ocean beaches (approximately $139 \mathrm{~km}^{2}$ ) (Fig. 1). Pamlico and Core Sounds are part of the PamlicoAlbemarle Estuarine Complex (PAEC), which is the second largest estuarine system in the United States. This system consists of shallow (mean depth of Pamlico Sound $=4.5 \mathrm{~m}$; Core Sound $=1.2 \mathrm{~m}$ ), productive, lagoonal-type ecosystems (Roelofs \& Bumpus 1953, Copeland \& Gray 1991) that are bounded on the east side by barrier islands. East of the barrier islands, the shallow waters of the continental shelf are influenced by the warm, fast-moving waters of the Gulf Stream and its frontal eddies (Lee et al. 1981, Pietrafesa et al. 1985).

\section{Aerial surveys}

A high-wing aircraft was used to survey 15 east-west oriented transects spaced $4.5 \mathrm{~km}$ apart (Fig. 1). The north-south starting point for the first transect was randomly selected to reduce sampling bias, as commonly implemented in systematic sampling designs (Cochran 1977, Eberhardt et al. 1979). With the exception of the eastern portion of the transects that extend into the coastal waters, the eastern and western endpoints of each transect reflect the boundaries of the MCAS Cherry Point's restricted airspace R-5306 A. Surveys were conducted at an altitude of $145 \mathrm{~m}$ and a ground speed of 165 to 


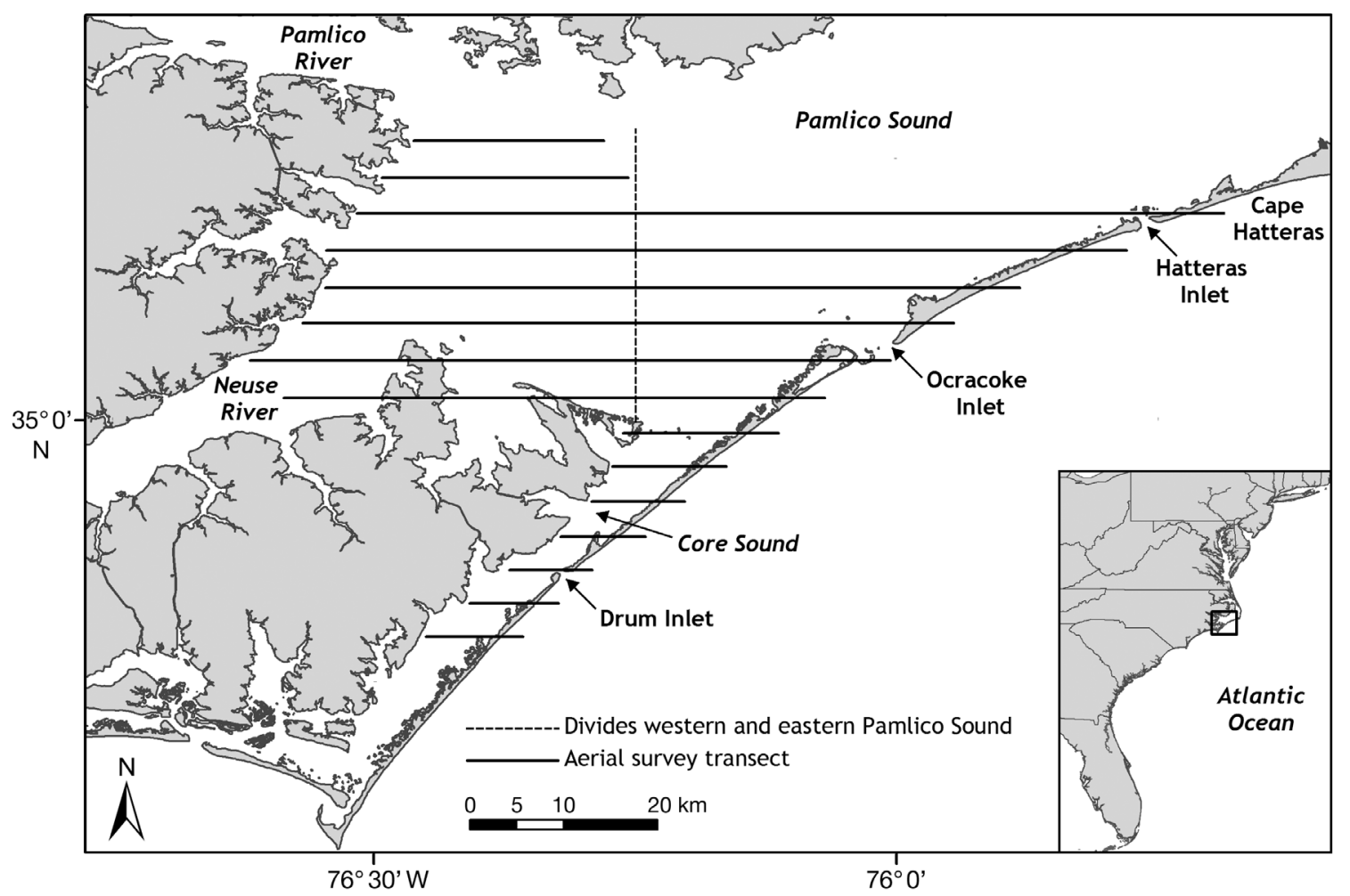

Fig. 1. Study site for aerial surveys of southern Pamlico and northern Core Sounds, and extending approximately $1.6 \mathrm{~km}$ from the coastline, North Carolina, July 2004 to April 2006. Inset shows location on the US east coast

$175 \mathrm{~km} \mathrm{~h}^{-1}$, using a Garmin GPS Map 295 to maintain position along each transect. Surveys lasted approximately $5 \mathrm{~h}$ and were scheduled so that mid-survey occurred close to noon to optimize light conditions. Although weekly surveys were attempted, flights occurred only when winds were $<18 \mathrm{~km} \mathrm{~h}^{-1}$ and wave height was $<0.6 \mathrm{~m}$, with no or few whitecaps (Beaufort sea state $\leq 3$ ).

During surveys, one trained observer was positioned on each side of the plane and reported sightings and environmental conditions (e.g. sea state, turbidity, weather, and glare) to a data recorder, who logged in geo-coordinates with a hand-held Garmin GPS 12XL. Leatherback turtles were the only marine turtles identified to species, as they are easier to distinguish from the air than cheloniid turtles (Goodman Hall \& Belskis 2012). All other turtles were assumed to be either loggerhead, Kemp's ridley, or green turtles, as these are the species most commonly encountered in North Carolina (Epperly et al. 2007). All dolphins were assumed to be bottlenose dolphins because they are the only dolphin species commonly inhabiting the survey region (Waring et al. 2011), and no obviously different species were observed. Dolphin group size was determined for each sighting by the direct count of individuals (if group size $\leq 10$ ani- mals), or was estimated in increments of 5 or 10 animals (if group size $>10$ animals). Commercial gill nets were identified by a pair of yellow buoys located on either end of the net as required by the NCDMF (NCDMF 2013).

\section{GIS analysis}

Geo-coordinates associated with each turtle, dolphin, and gill-net sighting were grouped seasonally and displayed using ArcGIS (version 9.2). Seasons were defined as spring (March to May), summer (June to August), autumn (September to November), and winter (December to February) (Epperly et al. 1995a, Steve et al. 2001). When describing the relative location of sightings in Pamlico Sound, we defined eastern Pamlico Sound as the region east of longitude $76^{\circ} 15^{\prime} 0^{\prime \prime} \mathrm{W}$ (denoted by a vertical broken line in Fig. 1), and western Pamlico Sound as the region west of this longitude.

Bottlenose dolphin, sea turtle, and gill-net sightings in the estuary were evaluated relative to water depth using a bathymetric layer downloaded from NOAA's National Geophysical Data Center website (NOAA 1989c). We did not examine the location of 
sightings in relation to water depth in the coastal waters due to the short distance that we surveyed from the shoreline. Water depth was binned in increments of $2 \mathrm{~m}$, to a maximum depth of $8 \mathrm{~m}$ (corresponding to the maximum depth of Pamlico Sound). The percentage of the survey region within each water depth bin was determined by outlining the area of each bin, and combining the area estimates of corresponding water depths. Dolphin, turtle, and gill-net sightings were then grouped by season, allowing for the occurrence of each sighting to be examined in relation to water depth among seasons.

We examined the autumn distribution of sea turtles in Pamlico Sound in relation to the designated shallow-water restricted areas within our study site where large-mesh gillnetting for southern flounder is allowed. The NCDMF refers to these areas as: the Shallow Gill Net Restricted Area (SGNRA) 1, SGNRA 2, and the Mainland Gill Net Restricted Area (MGNRA) (see Fig. 3). We obtained coordinates for the boundaries of these areas from the most recent NCDMF Proclamations (NCDMF 2011).

\section{SST}

SST data corresponding to survey days were extracted from $1.4 \mathrm{~km}$ pixel $^{-1}$ resolution Advanced Very High Resolution Radiometer (AVHRR) remote images collected by NOAA Polar Orbiting Environmental Satellites (NPOES) 15, 16, 17, and 18. Images were downloaded from the US southeastern regional node of NOAA's Comprehensive Large Array-data Stewardship System (CLASS) website (NOAA 1989a). Geocoordinates were digitally reconstructed along transects using Matlab software (The Mathworks Inc. 1994). SST data were indexed and extracted using row and column pixel locations. Any pixels identified by NOAA's Coastwatch as missing data, land, or clouds were excluded (NOAA 1989b). The mean value of the remaining pixels was used to obtain the mean SST of each survey. Extensive cloud cover prevented access to SST values for some survey days. During such cases, the mean SST for that particular survey day was estimated by calculating the mean SST from images within 2 consecutive days before and after the survey day.

\section{Data analysis}

We evaluated the relationship between mean SST and the total number of turtles and dolphins observed during surveys in the estuarine and coastal regions using Spearman's rank correlation coefficient.

GLMs (McCullagh \& Nelder 1989) in the form of Poisson regression were used to explore the effect of month, SST, year, and habitat type (coastal or estuarine) on counts of turtles, dolphin groups, and gill nets, while simultaneously accounting for possible confounding environmental factors (e.g. sea state, turbidity, weather, and glare) encountered during surveys. We used expectations from these fitted models ('predicted counts') to examine variation in the occurrence of turtles, dolphin groups, and gill nets as a function of explanatory variables. Modeling was conducted within an information-theoretic framework (Burnham \& Anderson 2002), allowing us to select parsimonious models that retained highly explanatory variables, while removing those with low explanatory power. We analyzed counts of dolphin groups instead of absolute numbers because groups could often be quite large, and initial attempts at analyzing absolute counts indicated considerable overdispersion relative to the Poisson distribution. Because the occurrence of sea turtles and dolphins in the coastal and estuarine habitats may be the result of different processes (e.g. migration vs. dispersal into nursery and/or foraging environments), transects that transversed both habitat types were split into 2 segments prior to analysis. Such transects thus contributed 2 counts for the analysis: one from the coastal segment and one from the estuarine. The variables 'month' and 'year' were treated as categorical variables, while SST was treated as a continuous variable. The total area surveyed $\left(\mathrm{km}^{2}\right)$ was calculated by multiplying the total length $(\mathrm{km})$ of all transects within a survey by the survey strip width $(0.15 \mathrm{~km}$ on both sides of the plane) (Epperly et al. 1995a), and was included as a log offset in all analyses to account for differences in area surveyed among transects. The exact position of sightings within the transect strip was not known, and, therefore, it is likely that some sightings included in the analysis were outside of the transect strip. However, we expect that the occurrence of these errors remained relatively constant over time, and thus, would not be expected to bias trends or inferences about seasonal dynamics. For turtle and dolphin datasets, we also included the following environmental categorical variables: sea state $(0=$ calm, $1=$ small waves, $2=$ moderate waves $)$; turbidity $(1=$ clear, $2=$ moderately turbid, 3 = very turbid); weather $(1=$ clear, 2 = partly cloudy, $3=$ cloudy, $4=$ drizzle, $5=$ rain, $6=$ haze $)$; and glare $(1=$ none, $2=\operatorname{mild}, 3=\bmod -$ erate, 4 = heavy). 
The Poisson distribution is often employed for the analysis of count data. As implemented here, the Poisson model assumes that the count of animals obtained on a given transect $\left(Y_{i}\right)$ is Poisson-distributed with intensity parameter $\lambda_{i}$, which is itself related to explanatory variables and regression parameters using a log link function:

$$
Y_{i} \sim \text { Poisson }\left(\lambda_{i}\right)
$$

where

$$
\log \left(\lambda_{i}\right)=\beta_{0}+\beta_{1} X_{i, 1}+\beta_{2} X_{i, 2}+\ldots+\beta_{\mathrm{n}} X_{i, \mathrm{n}}
$$

Here, the $\beta$ parameters indicate regression coefficients, and the $X_{i, j}$ represent the value of environmental covariate $j$ realized while observation $i$ was being obtained. In practice, ecological count data are often overdispersed relative to the Poisson distribution, meaning that the variance of counts exceeds the theoretical variance of the Poisson distribution (Ver Hoef \& Boveng 2007). It is thus important to test (and if need be, adjust) for overdispersion.

Each analysis proceeded by first fitting a 'global' model (see Table 3) to the data consisting of all possible main effects (due to the sparseness of our survey data, interactions between variables could not be estimated in many cases). Next, we conducted a deviance goodness-of-fit $\left(G^{2}\right)$ test from the global model to assess whether data were overdispersed relative to the Poisson distribution. Model selection was then conducted using a backwards stepwise selection algorithm (Venables \& Ripley 2002), whereby Akaike's information criterion, AIC (Burnham \& Anderson 2002) was used to determine which combination of variables resulted in the most parsimonious model fit. Starting with the global model, this algorithm involved sequentially dropping terms that have minimal impact on predictions of turtle, dolphin, or gillnet counts. All variables were treated as additive on the log scale, with the exception of month and habitat type, which were allowed to interact in the global model.

We used the function 'glm' in the R statistical language ( $\mathrm{R}$ Development Core Team 2007) to fit regression models. For selected models that did not include year effects, we used the R function 'predict.glm' to generate expected densities and standard errors for turtles, dolphin groups, and gill nets that would have resulted had surveys been conducted under favorable sightability conditions (i.e. at the lowest levels of glare, turbidity, weather, and Beaufort sea state). For final models that did include year effects, we computed a mean prediction across years; requisite $\mathrm{R}$ code is available from the third author.

\section{RESULTS}

Forty-one aerial surveys were completed from July 2004 to April 2006 (Table 1). Surveys were not conducted during December 2004, January 2005, or April 2005 due to logistical constraints and inclement weather. Overall, surveys covered $6350 \mathrm{~km}^{2}$ in the estuary and $234 \mathrm{~km}^{2}$ along the coast. A total of 1559 bottlenose dolphins (340 groups), 86 sea turtles (all cheloniids), and 378 gill nets were observed. Dolphins were observed year-round in the estuary and along the coast; turtles were observed from April to November in both habitats. Gill nets were observed all months except for January and December in both habitats.

Within the estuary, our aerial observations indicated that the spatial overlap of turtles and gill nets occurred predominantly in eastern Pamlico Sound in spring, throughout the estuary during summer, and in eastern Pamlico and Core Sounds in autumn (Fig. 2). Spatial overlap of dolphins and gill nets occurred throughout the estuary from spring to autumn, but was limited to eastern Pamlico Sound in winter. In the coastal region, turtle and dolphin distribution predominantly overlapped with gill nets in the region extending from Cape Hatteras to just south of Ocracoke Inlet from spring to autumn. Seasonally, the majority of dolphins (57 to $75 \%$ ) and gill nets (80 to $88 \%$ ) were seen in shallow water $<2 \mathrm{~m}$ deep in the estuary (Fig. 2, Table 2). Turtles (75\%) were seen most often in shallow water in spring. During autumn, the majority of turtles ( $89 \%$ ) were observed outside of the SGNRAs 1 and 2, and no turtles were observed in the boundaries of the MGNRA (Fig. 3).

The occurrence of turtles and dolphins was significantly, but weakly, correlated with SST. Dolphins were observed throughout the range of mean survey SST $\left(7.6\right.$ to $30.8^{\circ} \mathrm{C}$ ) (Table 1$)$, and counts in estuarine $(\mathrm{r}=-0.38, \mathrm{p}=0.013)$ and coastal $(\mathrm{r}=-0.48, \mathrm{p}<0.001)$ waters decreased as SST increased. Turtles were observed when mean survey SST ranged from 9.7 to $30.8^{\circ} \mathrm{C}$ (Table 1$)$, and counts in estuarine $(\mathrm{r}=0.53, \mathrm{p}<$ 0.001 ) and coastal ( $\mathrm{r}=0.39, \mathrm{p}=0.011$ ) waters increased as SST increased.

The Poisson GLMs fit our data reasonably well, with little to no evidence for overdispersion (turtles: $G^{2}=315$, df = 1066, p = 0.99; dolphins: $G^{2}=904, \mathrm{df}=$ 1066, $\mathrm{p}=0.99$; gill nets: $G^{2}=1115$, df $=1067, \mathrm{p}=$ 0.15). The Poisson regression model that best explained our aerial observations for turtles included additive effects of month, habitat type, SST, glare, and sea state (Table 3, Fig. 4). The absence of a 'year' effect in the selected GLM indicates that monthly trends in predicted counts of turtles did not vary sub- 
Table 1. Sea turtles, bottlenose dolphins Tursiops truncatus, and gill nets observed during aerial surveys of the estuarine (Pamlico and Core Sounds) and coastal waters of North Carolina, July 2004 to April 2006. SST: sea surface temperature

\begin{tabular}{|c|c|c|c|c|c|c|c|c|c|c|c|c|}
\hline \multirow{2}{*}{ Year } & \multirow{2}{*}{ Survey } & \multirow{2}{*}{$\begin{array}{c}\text { Mean } \\
\text { survey } \\
\mathrm{SST}\left({ }^{\circ} \mathrm{C}\right)\end{array}$} & \multirow[b]{2}{*}{$\begin{array}{c}\text { Area } \\
\text { surveyed } \\
\left(\mathrm{km}^{2}\right)\end{array}$} & \multirow[b]{2}{*}{ Turtles } & \multirow{2}{*}{$\begin{array}{c}\text { Estuarine }- \\
\text { Dolphin } \\
\text { sightings }\end{array}$} & \multirow[b]{2}{*}{$\begin{array}{c}\text { Total } \\
\text { dolphins }\end{array}$} & \multirow[b]{2}{*}{$\begin{array}{l}\text { Gill } \\
\text { nets }\end{array}$} & \multirow[b]{2}{*}{$\begin{array}{c}\text { Area } \\
\text { surveyed } \\
\left(\mathrm{km}^{2}\right)\end{array}$} & \multirow[b]{2}{*}{ Turtles } & \multirow{2}{*}{$\begin{array}{c}\text { - Coastal - } \\
\text { Dolphin } \\
\text { sightings }\end{array}$} & \multirow[b]{2}{*}{$\begin{array}{c}\text { Total } \\
\text { dolphins }\end{array}$} & \multirow[b]{2}{*}{$\begin{array}{l}\text { Gill } \\
\text { nets }\end{array}$} \\
\hline & & & & & & & & & & & & \\
\hline \multirow{13}{*}{2004} & $10 \mathrm{Jul}$ & 29.8 & 170 & 1 & 3 & 6 & 1 & 5.7 & 0 & 2 & 9 & 0 \\
\hline & $25 \mathrm{Jul}$ & 29.2 & 181 & 5 & 3 & 12 & 2 & 5.7 & 0 & 0 & 0 & 0 \\
\hline & 8 Aug & 25.9 & 176 & 0 & 3 & 12 & 5 & 5.7 & 1 & 0 & 0 & 0 \\
\hline & 19 Aug & 27.4 & 169 & 2 & 5 & 19 & 4 & 5.7 & 1 & 1 & 3 & 0 \\
\hline & 27 Aug & 27.2 & 182 & 1 & 1 & 5 & 9 & 5.7 & 0 & 0 & 0 & 0 \\
\hline & $4 \mathrm{Sep}$ & 27.2 & 149 & 0 & 0 & 0 & 8 & 5.7 & 0 & 1 & 1 & 0 \\
\hline & 3 Oct & 24.7 & 152 & 0 & 3 & 22 & 1 & 5.7 & 3 & 2 & 2 & 0 \\
\hline & $10 \mathrm{Oct}$ & 23.0 & 151 & 0 & 2 & 10 & 1 & 5.7 & 0 & 2 & 2 & 0 \\
\hline & 24 Oct & 18.8 & 155 & 0 & 4 & 63 & 11 & 5.7 & 0 & 3 & 11 & 0 \\
\hline & 29 Oct & 16.9 & 147 & 1 & 2 & 14 & 30 & 5.7 & 0 & 7 & 21 & 0 \\
\hline & $6 \mathrm{Nov}$ & 18.3 & 147 & 0 & 5 & 30 & 23 & 5.7 & 0 & 16 & 51 & 5 \\
\hline & $11 \mathrm{Nov}$ & 14.1 & 148 & 1 & 3 & 11 & 27 & 5.7 & 0 & 3 & 10 & 1 \\
\hline & $20 \mathrm{Nov}$ & 12.7 & 152 & 3 & 8 & 88 & 5 & 5.7 & 0 & 10 & 78 & 0 \\
\hline \multirow[t]{21}{*}{2005} & 13 Feb & 7.9 & 154 & 0 & 2 & 18 & 10 & 5.7 & 0 & 19 & 87 & 0 \\
\hline & 6 Mar & 8.0 & 170 & 0 & 4 & 9 & 13 & 5.7 & 0 & 7 & 20 & 1 \\
\hline & 14 May & 20.1 & 160 & 0 & 0 & 0 & 10 & 5.7 & 4 & 3 & 15 & 0 \\
\hline & 22 May & 17.9 & 154 & 0 & 1 & 4 & 10 & 5.7 & 0 & 3 & 18 & 0 \\
\hline & 30 May & 20.1 & 154 & 2 & 5 & 11 & 18 & 5.7 & 2 & 2 & 9 & 0 \\
\hline & 4 Jun & 20.6 & 153 & 0 & 2 & 4 & 12 & 5.7 & 0 & 0 & 0 & 0 \\
\hline & 11 Jun & 25.2 & 159 & 3 & 2 & 15 & 14 & 5.7 & 8 & 5 & 25 & 0 \\
\hline & 18 Jun & 26.7 & 158 & 2 & 1 & 2 & 7 & 5.7 & 4 & 0 & 0 & 0 \\
\hline & 24 Jun & 25.3 & 156 & 0 & 1 & 6 & 4 & 5.7 & 4 & 2 & 11 & 0 \\
\hline & $3 \mathrm{Jul}$ & 27.1 & 149 & 1 & 0 & 0 & 0 & 5.7 & 2 & 0 & 0 & 0 \\
\hline & $9 \mathrm{Jul}$ & 27.5 & 149 & 2 & 2 & 2 & 15 & 5.7 & 1 & 1 & 5 & 0 \\
\hline & 6 Aug & 30.8 & 153 & 4 & 1 & 1 & 8 & 5.7 & 4 & 5 & 72 & 3 \\
\hline & 21 Aug & 30.4 & 151 & 2 & 1 & 2 & 8 & 5.7 & 1 & 3 & 19 & 0 \\
\hline & 2 Sep & 29.6 & 151 & 4 & 2 & 3 & 12 & 5.7 & 1 & 3 & 23 & 1 \\
\hline & 9 Oct & 20.5 & 148 & 1 & 0 & 0 & 3 & 5.7 & 1 & 0 & 0 & 0 \\
\hline & 30 Oct & 24.6 & 151 & 1 & 4 & 9 & 25 & 5.7 & 0 & 4 & 22 & 0 \\
\hline & $6 \mathrm{Nov}$ & 17.9 & 149 & 8 & 4 & 12 & 11 & 5.7 & 0 & 9 & 30 & 1 \\
\hline & $20 \mathrm{Nov}$ & 17.1 & 149 & 0 & 2 & 4 & 16 & 5.7 & 1 & 5 & 20 & 1 \\
\hline & $27 \mathrm{Nov}$ & 9.7 & 149 & 0 & 3 & 16 & 1 & 5.7 & 1 & 4 & 12 & 0 \\
\hline & $10 \mathrm{Dec}$ & 10.8 & 152 & 0 & 6 & 34 & 0 & 5.7 & 0 & 12 & 43 & 0 \\
\hline & $23 \mathrm{Dec}$ & 7.6 & 155 & 0 & 7 & 32 & 0 & 5.7 & 0 & 18 & 124 & 0 \\
\hline \multirow[t]{7}{*}{2006} & 21 Jan & 9.4 & 149 & 0 & 2 & 4 & 0 & 5.7 & 0 & 2 & 8 & 0 \\
\hline & $28 \mathrm{Jan}$ & 11.2 & 148 & 0 & 0 & 0 & 0 & 5.7 & 0 & 5 & 27 & 0 \\
\hline & $25 \mathrm{Feb}$ & 10.5 & 156 & 0 & 3 & 5 & 4 & 5.7 & 0 & 10 & 32 & 0 \\
\hline & $11 \mathrm{Mar}$ & 15.0 & 149 & 0 & 1 & 12 & 21 & 5.7 & 0 & 17 & 43 & 0 \\
\hline & 31 Mar & 15.1 & 148 & 0 & 8 & 24 & 4 & 5.7 & 0 & 25 & 114 & 0 \\
\hline & 16 Apr & 19.6 & 149 & 1 & 4 & 8 & 5 & 5.7 & 0 & 7 & 14 & 0 \\
\hline & 23 Apr & 21.7 & 150 & 0 & 10 & 44 & 7 & 5.7 & 2 & 2 & 5 & 0 \\
\hline Total & & & 6350 & 45 & 120 & 573 & 365 & 234 & 41 & 220 & 986 & 13 \\
\hline
\end{tabular}

stantially from year to year. Predicted counts were also greater in coastal than estuarine waters during all seasons, while exhibiting similar monthly trends in the estuary and along the coast, with the highest counts occurring in late spring and late autumn, and a smaller peak in late summer.

The highest supported model for dolphin groups included main effects of month, habitat type, year, turbidity, glare, and sea state, as well as an interaction between month and habitat type (Table 3 , Fig. 4). Predicted counts of dolphins were highest in spring and late autumn-early winter in the estuary, and from late autumn to early spring (with the exception of January) along the coast. Predicted counts were higher in coastal than estuarine waters during all seasons. 


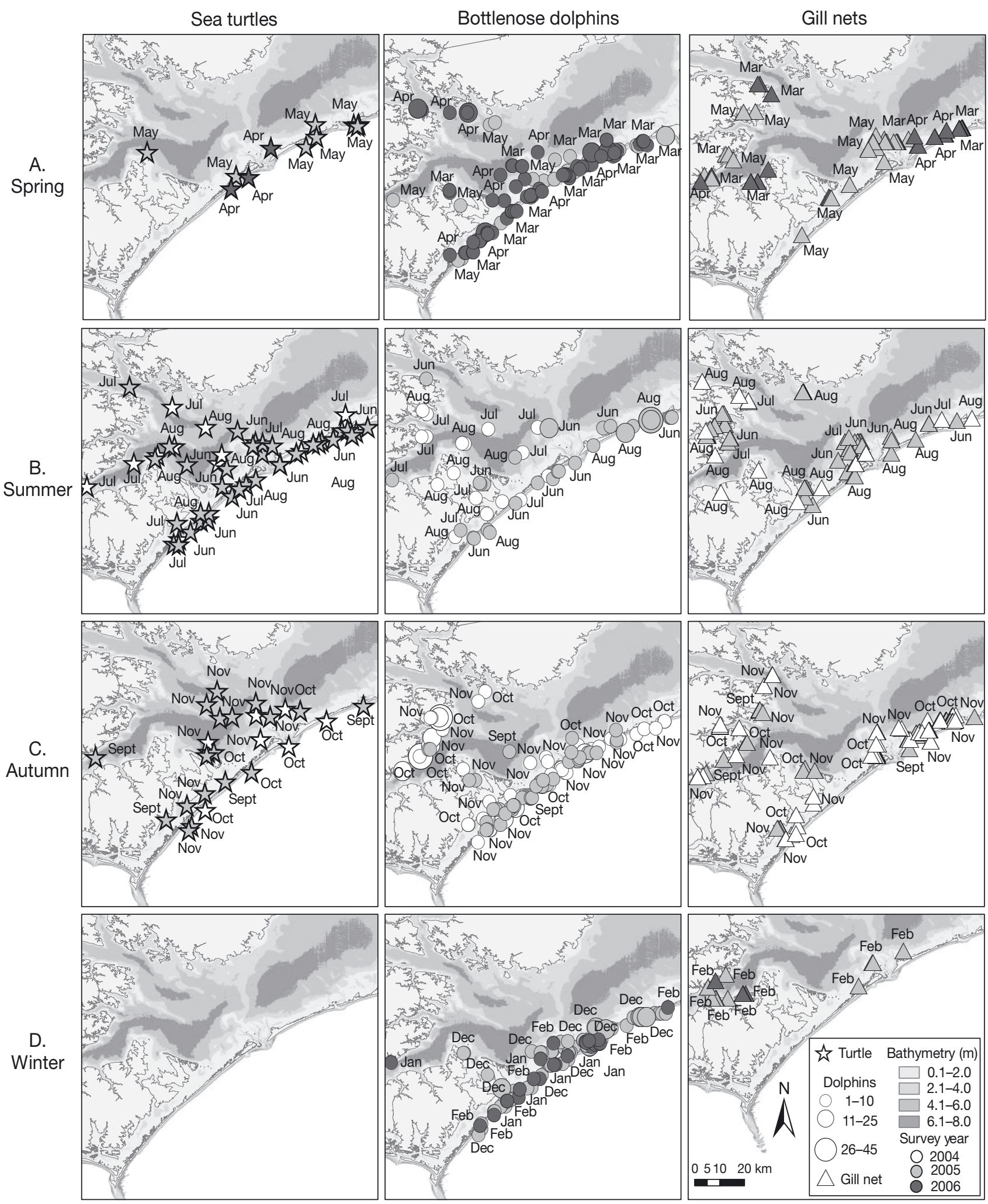

Fig. 2. Seasonal distribution of sea turtles (left panel), bottlenose dolphins Tursiops truncatus (middle panel), and gill nets (right panel) relative to water depth in North Carolina, USA, in (A) spring (Mar-May, n = 8), (B) summer (Jun-Aug, n = 13), (C) autumn (Sep-Nov, $n=14$ ), and (D) winter (Dec-Feb, $n=8)$. Each symbol represents a single sighting. Survey effort (n) differed among seasons; thus, the number of sightings may reflect differences in effort, not actual abundance 
Table 2. Sea turtle, bottlenose dolphin Tursiops truncatus, and gill net distribution in Pamlico and Core Sounds, North Carolina, in relation to water depth. Data are presented as percentages of the total number of sightings at each water depth for each season. Winter water depth data are not available (na) for sea turtles because they were not observed during this time. Percentages within parentheses beneath each water depth bin refer to the percentage of total estuarine waters within that water depth bin

\begin{tabular}{|lcccc|}
\hline \multirow{2}{*}{ Season } & \multicolumn{5}{c|}{ Estuarine water depth $(\mathrm{m})$} \\
& $\begin{array}{c}0.1-2.0 \\
(31 \%)\end{array}$ & $\begin{array}{c}2.1-4.0 \\
(22 \%)\end{array}$ & $\begin{array}{c}4.1-6.0 \\
(27 \%)\end{array}$ & $\begin{array}{c}(20 \%) \\
(20.0\end{array}$ \\
\hline Sea turtles & & & & \\
Spring & 75 & 0 & 25 & 0 \\
Summer & 32 & 12 & 40 & 16 \\
Autumn & 26 & 22 & 26 & 26 \\
Winter & na & na & na & na \\
Bottlenose dolphins & & & & \\
Spring & 57 & 23 & 13 & 7 \\
Summer & 58 & 21 & 17 & 4 \\
Autumn & 75 & 19 & 3 & 3 \\
Winter & 61 & 39 & 0 & 0 \\
Gill nets & & & & \\
Spring & 80 & 13 & 7 & 0 \\
Summer & 81 & 18 & 0 & 1 \\
Autumn & 88 & 8 & 1 & 3 \\
Winter & 86 & 14 & 0 & 0 \\
\hline
\end{tabular}

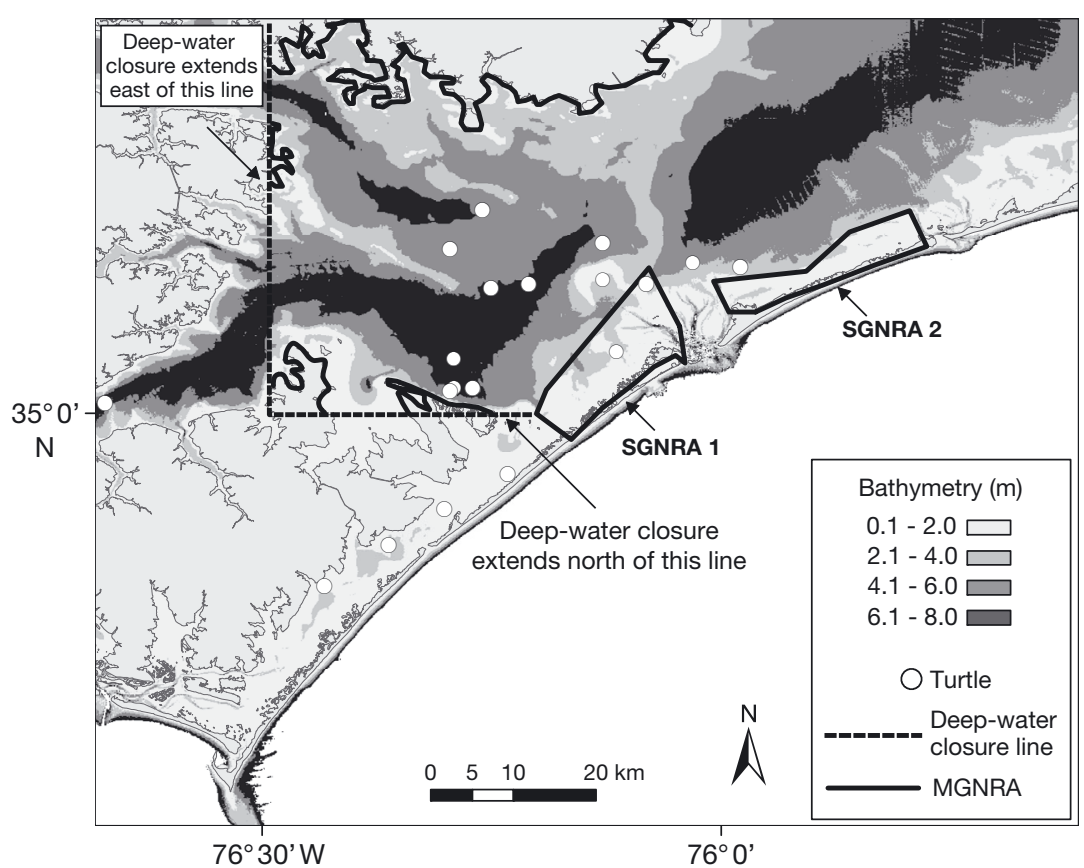

Fig. 3. Autumn (Sep-Nov) distribution of sea turtles observed in estuarine waters in relation to water depth, and regulated areas of Pamlico Sound, North Carolina, 2004 to 2006. The large-mesh gill-net fishery is prohibited in the deep waters ( 3 to $6 \mathrm{~m}$ ) of the sound, the western and southern borders of which are shown as dashed lines. Large-mesh gillnetting is allowed in: Shallow Gill Net Restricted Area (SGNRA) 1, SGNRA 2, and the Mainland Gill Net Restricted Area (MGNRA). The MGNRA extends 200 yards $(183 \mathrm{~m})$ from the shoreline, and is encompassed within the solid black line that outlines its boundary. Each symbol represents a single turtle sighting
Counts of gill nets varied as a function of month, year, turbidity, SST, glare, and weather (Table 3). In contrast to turtle and dolphin GLMs, there did not appear to be a difference in the apparent density of gill nets as a function of habitat type (estuary vs. coast). Predictions of gill-net counts over standardized sightability conditions (Fig. 4) suggested no fisheries effort in December and January, a medium level of effort in the spring and summer, and maximum effort in autumn (September to November).

\section{DISCUSSION}

The management of sea turtle and bottlenose dolphin interactions with commercial gill nets in North Carolina's waters is complicated by a need for more information regarding specific times and locations where habitat use is likely to overlap. In the present study, we found that sea turtles and bottlenose dolphins exhibited distinct seasonal patterns of habitat use within our study site, and that consideration of these patterns may aid with the identification of times and locations where turtles and dolphins are most likely to co-occur with gill nets. For sea turtles, habitat use appeared to be largely driven by seasonal migration patterns, which are strongly linked to water temperature. However, habitat use by bottlenose dolphins appeared to be more closely tied to the seasonal movements of prey that they feed upon.

Our aerial observations indicated that gill nets were distributed throughout the survey region year-round; however, sea turtle distribution varied seasonally. For instance, turtles were predominantly observed in the eastern portion of the estuary in spring upon migration into these waters as water temperature increased, and in autumn as water temperature declined and turtles moved back into the eastern portion of the estuary prior to winter emigration. However, turtles were distributed throughout the estuary (including the eastern portion of the Pamlico and Neuse Rivers) during summer. These findings may suggest that sea turtle bycatch in gill nets may be more likely to occur in the eastern portion of the estuary in spring and autumn, but that interactions could occur throughout the estuary during summer. 
Table 3. Stepwise model selection criterion, starting with the global model, for sea turtles, bottlenose dolphins Tursiops truncatus, and gill nets. The number of parameters $(k)$ and AIC score are presented for each model, and the selected model for each dataset is presented in bold. Here, 'Type' gives habitat type (estuarine or coastal), and 'Sea' gives Beaufort sea state. SST: sea surface temperature

\begin{tabular}{|c|c|c|}
\hline Model & $k$ & AIC \\
\hline \multicolumn{3}{|l|}{ Sea turtles } \\
\hline Month $\times$ Type + Year + Turbidity + SST + Glare + Sea + Weather & 40 & 549.3 \\
\hline Month $\times$ Type + Year + Turbidity + SST + Glare + Sea & 35 & 544.2 \\
\hline Month $\times$ Type + Turbidity + SST + Glare + Sea & 32 & 541.9 \\
\hline Month $\times$ Type + SST + Glare + Sea & 30 & 539.4 \\
\hline Month + Type + SST + Glare + Sea & 19 & 538.3 \\
\hline Type + SST + Glare + Sea & 8 & 561.1 \\
\hline Month + SST + Glare + Sea & 18 & 689.7 \\
\hline Month + Type + Glare + Sea & 18 & 556.6 \\
\hline Month + Type + SST + Glare & 16 & 544.8 \\
\hline Month + Type + SST + Sea & 17 & 543.0 \\
\hline \multicolumn{3}{|l|}{ Bottlenose dolphins } \\
\hline Month $\times$ Type + Year + Turbidity + SST + Glare + Sea + Weather & 40 & 1483.1 \\
\hline Month $\times$ Type + Year + Turbidity + SST + Glare + Sea & 35 & 1479.3 \\
\hline Month $\times$ Type + Year + Turbidity + Glare + Sea & 34 & 1477.3 \\
\hline Month $\times$ Type + Year + Turbidity + Glare & 30 & 1480.7 \\
\hline Month $\times$ Type + Year + Turbidity + Sea & 28 & 1485.6 \\
\hline Month $\times$ Type + Year + Glare + Sea & 27 & 1503.8 \\
\hline Month $\times$ Type + Turbidity + Glare + Sea & 26 & 1479.8 \\
\hline Month + Type + Year + Turbidity + Glare + Sea & 13 & 1483.7 \\
\hline \multicolumn{3}{|l|}{ Gill nets } \\
\hline Month $\times$ Type + Year + Turbidity + SST + Glare + Sea + Weather & 40 & 1543.3 \\
\hline Month + Type + Year + Turbidity + SST + Glare + Sea + Weather & 29 & 1532.2 \\
\hline Month + Type + Year + Turbidity + SST + Glare + Weather & 27 & 1529.9 \\
\hline Month + Year + Turbidity + SST + Glare + Weather & 26 & 1527.9 \\
\hline Month + Year + Turbidity + SST + Glare & 21 & 1561.6 \\
\hline Month + Year + Turbidity + SST + Weather & 23 & 1528.5 \\
\hline Month + Year + Turbidity + Glare + Weather & 25 & 1529.8 \\
\hline Month + Year + SST + Glare + Weather & 24 & 1532.2 \\
\hline Month + Turbidity + SST + Glare + Weather & 23 & 1530.7 \\
\hline Year + Turbidity + SST + Glare + Weather & 15 & 1628.4 \\
\hline
\end{tabular}

have been present, but were spending more time below the water's surface where they were not visible to observers (e.g. engaged in benthic foraging) (Byles 1988, Keinath 1993, Keinath et al. 1996, Nelson 1996, Mansfield 2006, TEWG 2009). Likewise, increased turtle counts in the estuary in autumn could be the result of turtles moving back into the study site before emigrating from the estuary, or an increase in time spent at the water's surface.

The absence of turtle observations when mean survey SST was below $9.7^{\circ} \mathrm{C}$ (consistent with their lower thermal limit of 8 to $10^{\circ} \mathrm{C}$; Schwartz 1978, Morreale et al. 1992, Spotila et al. 1997), and the significant positive correlation between turtle counts and increasing water temperature, is indicative of the influence that water temperature has on the occurrence of turtles within this region. However, the weakness of the correlation suggests that once water temperature has risen above the lower thermal limit of turtles, their abundance is also influenced by additional factors (e.g. foraging strategies, mating areas). Seasonal regulations based on a minimum water temperature $\left(11^{\circ} \mathrm{C}\right)$ below which the likelihood of encountering turtles is decreased have been used to manage sea turtlefishery interactions in the coastal

Counts of sea turtles and gill nets were elevated concurrently in spring and autumn, possibly further increasing risk of interactions during this time. Gillnet effort in North Carolina's waters is typically elevated in spring and autumn (Steve et al. 2001). Elevated turtle counts in spring and autumn in coastal waters may have been related to the seasonal migration of turtles along the coast (Shoop \& Kenney 1992, Keinath et al. 1996, Hawkes et al. 2007, McClellan \& Read 2007, Mansfield et al. 2009), while increased turtle counts in the estuary in spring were also likely related to the repopulation of this region as estuarine waters warmed (Epperly et al. 1995a). Decreased counts in early/ mid-summer may have been the result of turtles dispersing throughout the estuary, and thus moving into areas outside of our study site, or turtles may waters off North Carolina and Virginia (NMFS 1996, 2001, 2002a), and also may be helpful for managing gill-net interactions in the estuarine waters of North Carolina.

Similar to sea turtles, bottlenose dolphins displayed distinct seasonal patterns of movement and variations in predicted counts that may help identify locations and times when interactions with gill nets may be more prevalent. However, because of the yearround presence of dolphins in North Carolina, it is likely that their abundance and movements are more closely related to the effects of water temperature on prey distribution than to their thermal tolerance. For instance, gill-net landings for spot Leiostomus xanthurus and Atlantic croaker Micropogonias undulatus, the primary prey of dolphins in North Carolina's estuarine waters (Gannon \& Waples 2004), are ele- 

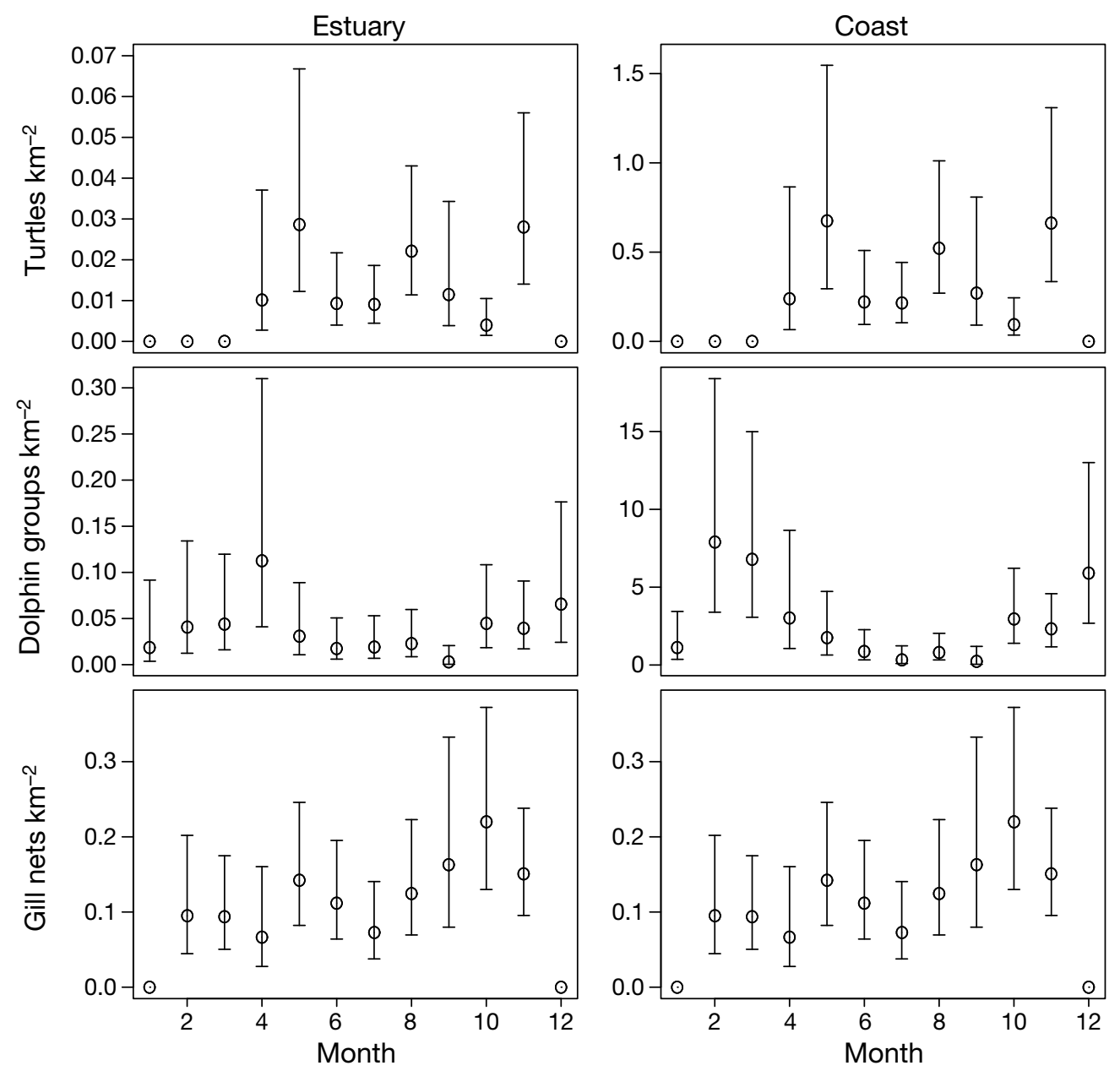

Fig. 4. Model-based surface count predictions for sea turtles (top), bottlenose dolphin Tursiops truncatus groups (middle), and gill nets (bottom) by month, for estuarine (left) and coastal waters (right). All predictions are made under standardized visibility and environmental conditions (i.e. no glare, calm seas, clear skies, no or low turbidity). Error bars give $95 \%$ confidence intervals. Note that the $y$-axis values differ among graphs

vated in the counties surrounding Pamlico and Core Sounds in spring and autumn (Wilson 1997, Steve et al. 2001, Gannon \& Waples 2004). Dolphin counts were also elevated in the estuary during these times, but declined in mid-winter when dolphins moved into the eastern portion of the estuary (and presumably into the coastal waters as well; Waring et al. 2011), corresponding with the emigration of these fish species from the estuary (Pacheco 1962, Chao \& Musick 1977, Warlen 1980). Likewise, in the coastal waters, the southward migration of dolphins from northern locations has been attributed to an increase in the number of dolphins south of Cape Hatteras during winter (Kenney 1990, Torres et. al 2005, Waring et al. 2011). This wintertime increase in dolphin abundance was also apparent in our study, and corresponds with the formation of large aggregations of weakfish Cynoscion regalis (a dominant food source for dolphins during winter in North Carolina; Gannon \& Waples 2004) south of Cape Hatteras (Pearson 1932, Wilk 1979). Additionally, the migration of dolphins (from northern locations) into the coastal waters of North Carolina during winter, and the movement of dolphins out of the estuary during this time, likely explains the slightly stronger correlation between dolphin counts and decreasing water temperature in the coastal waters.

Although specific stocks of dolphins could not be identified during our aerial surveys, the higher predicted counts of dolphin groups in the coastal habitat compared to the estuary among all seasons is probably the result of the distribution of dolphin stocks in North Carolina and their respective population sizes. For example, the majority of dolphins we observed in the estuary likely belong to the NNCES, which has a much smaller population size (Read et al. 2003) than 
the 2 migratory stocks, the NMCS and SMCS (Torres et al. 2005, Waring et al. 2011).

In the nearshore coastal waters, turtle and dolphin distribution often overlapped with gill nets in the region extending from Cape Hatteras to just south of Ocracoke Inlet, possibly indicating increased risk of interactions in this area. The abundance of gill nets in this particular region may result from factors such as the occurrence of aggregations of fish, and the accessibility provided to the area by 2 stable inlets. In addition, although historical gill-net activity is elevated in winter along the coast of North Carolina (Wilson 1997, Steve et al. 2001), concurrent with the highest counts of dolphins during the current surveys, we found that gill-net counts were not heightened along the coast during this time. The wintertime discrepancy between our analysis and historical gill-net activity may be due to an actual decrease in gill-net effort (Byrd et al. 2008), or to the limited geographic coverage of our surveys relative to the entire range of the winter gill-net fishery (Steve et al. 2001). Gill-net effort can also vary greatly within a season (Kolkmeyer et al. 2009), and we might not have surveyed during the highest level of gill-net activity.

Our approach in the present paper was to use GLMs to account for various environmental and observation factors (e.g. turbidity, glare, weather, sea state) that affected our ability to count sea turtles, dolphin groups, and gill nets. Predictions from fitted models (e.g. Fig. 4) could thus be made for optimized sighting conditions, controlling for sampling artifacts that were not of interest. However, predictions made in this manner are still an index in the sense that animals (and gill nets) may still be imperfectly detected even under good sightability conditions. For instance, aerial abundance estimates for sea turtles are negatively biased, because turtles spend the majority of their time below the water's surface, where they are not visible to observers (Epperly et al. 1995a, Mansfield 2006, TEWG 2009). In addition, telemetry studies of sea turtles indicate that the amount of time spent on the water's surface also may vary seasonally due to behavior (e.g. migration near the water's surface vs. benthic foraging), and/or environmental conditions such as water temperature (i.e. turtles spending more time in warmer surface waters in early spring) (Byles 1988, Keinath 1993, Keinath et al. 1996, Nelson 1996, Mansfield 2006, TEWG 2009).

Similar to dolphins, predicted counts of turtles were greater in the coastal habitat compared to the estuary among all seasons. While it is possible that turtle density may actually be greater in the coastal region, differences in surfacing behavior between the 2 habitats may also have influenced our aerial counts. For example, satellite-tagged loggerhead turtles in North Carolina's waters were found to spend significantly more time at the surface while in coastal waters compared to the estuary during all seasons (Braun-McNeill et al. 2010). Additional telemetry studies of sea turtles in these waters would be beneficial to clarify the influence that geographical variations in surfacing behavior may have on aerial estimates of abundance.

The results of the present study and of satellitetracked turtles (McClellan et al. 2009) confirm high use of deep-water areas (where gillnetting is not allowed) of eastern Pamlico Sound during autumn and support continued regulations there to reduce sea-turtle bycatch. However, it is important to note that our observations were likely biased towards larger turtles, as they are easier to see from higher altitudes. Green sea turtles frequently forage on seagrass beds in shallow water (McClellan \& Read 2009, McClellan et al. 2009), and are now the most commonly captured species in the shallow-water gill-net restricted areas of Pamlico Sound (Daniel 2012). Long-term studies of sea turtles in North Carolina's estuarine waters have indicated the median size of loggerhead, Kemp's ridley, and green sea turtles to be $61.6,42.2$, and $32.2 \mathrm{~cm}$, respectively (Epperly et al. 2007). Although not identified as such, the size, shape, and color of the majority of turtles we observed was consistent with that of loggerhead turtles. Thus, the seasonal distribution of green and Kemp's ridley turtles may have been underrepresented during our surveys. In addition, large-mesh gill nets are restricted to designated shallow-water regions of Pamlico Sound during autumn, but we also predominantly observed gill nets in shallow $(\leq 2 \mathrm{~m})$ estuarine waters in all other seasons. Therefore, risk of entanglement may be increased when turtles frequent these regions, such as in spring, when the majority of turtles were observed in shallow waters.

High use of the shallow estuarine waters by gill-net fishers and dolphins in all seasons may indicate that they are utilizing similar geographic features to capture fish. For instance, gill nets are often set perpendicular to shoals or near marsh islands because these features direct fish towards the nets (Steve et al. 2001). Similar to our observations in the estuary, Gannon (2003) observed dolphins frequently using the shallow waters $(<3.5 \mathrm{~m})$ of the Neuse River during boat-based surveys, and suggested that they may use the steep banks of the river to enhance the capture of prey. Likewise, dolphins in other estuarine systems preferred feeding over or near shallow waters (Scott et al. 1996, Barros \& Wells 1998). 
The amount of time that gill nets remain in the water (soak time) and when they are set (day or night) may be influenced by factors such as weather conditions, fishing regulations, and the species targeted (Steve et al. 2001). Because our surveys only occurred during the day, gill nets set in the evening and removed in the early morning may not have been detected. Furthermore, gill nets that were removed in the morning would be less likely to be detected in the northern portion of our survey area since surveys always started in the southern region. Therefore, overlap in habitat use among turtles and dolphins with gill nets at night would be poorly represented by our surveys.

The present study provided a unique opportunity to concurrently examine the year-round seasonal occurrence of sea turtles, bottlenose dolphins, and gill nets in North Carolina's estuarine and coastal waters. Within North Carolina's coastal waters, risk of entanglement in gill nets has long been recognized, and federal observer programs have been used to estimate bycatch levels of turtles and dolphins (Murray 2009, Waring et al. 2011). In contrast, management of estuarine waters has not been as comprehensive, and has largely been in response to increased levels of bycatch or stranding events (NMFS 1999, NCDMF 2009), instead of a comprehensive approach to a gear that is known to take sea turtles and dolphins. Information presented here indicates that specific areas and times when turtles and dolphins may be more likely to interact with gill nets in these waters can be identified due to the distinct seasonal patterns of habitat use exhibited by these species. Such knowledge can help finetune the allocation of observer coverage, and highlights potential times and areas where coverage may not be representative of the fishery. The present study also shows risk of turtle bycatch outside of the designated gill net restricted areas in Pamlico Sound and during seasons other than autumn, further supporting the need for bycatch estimates and possible conservation measures in other areas and among other seasons. Furthermore, knowledge obtained of seasonal changes in habitat use and abundance of dolphins and turtles leads to a greater understanding of important habitat for the species, and will also help mitigate interactions with other fisheries in these waters.

Acknowledgments. We thank the pilots (G. Ambrose, L. Gibbs, C. Hinkley, M. Honeycutt, J. Meagher, and P. Platt), and observers (J. Altman, T. Bean, D. Blackwood, R. Clayton, W. Cluse, B. Daniels, J. Dyble, R. Ferguson, W. Gainey, M. Godfrey, L. Goshe, L. Grimes, G. Haught, S. Huntsman,
E. Jugovich, S. Kubis, B. Luna, B. Price, C. Price, B. Rogers, and $\mathrm{C}$. TenBrink) who contributed to this project. We also appreciate valuable suggestions provided by L. Avens, B. Byrd, A. Chester, S. Epperly, L. Goshe, N. Hall, L. Hansen, P. Marraro, B. Price, and 3 anonymous reviewers, statistical advice from E. Griffith, and GIS insights from B. Byrd and D. Field. Funding was provided by The United States Department of the Navy, MCAS Cherry Point and the National Marine Fisheries Service (NMFS). The NMFS does not approve, recommend, or endorse any proprietary product or material mentioned in this publication. Aerial surveys were conducted under NMFS Scientific Research Permit No. 1260.

\section{LITERATURE CITED}

ASMFC (Atlantic States Marine Fisheries Commission) (2002) Amendment 4 to the interstate fishery management plan for weakfish. Fishery Management Report No. 39. ASMFC, Arlington, VA

ASMFC (Atlantic States Marine Fisheries Commission) (2008) Interstate fishery management plan for Atlantic coastal sharks. Fishery Management Report No. 46. ASMFC, Arlington, VA

Barlow J, Swartz SL, Eagle TC, Wade PR (1995) US marine mammal stock assessments: guidelines for preparation, background, and a summary of the 1995 assessments. NOAA Tech Memo NMFS-OPR-95-6. NMFS, Silver Spring, MD

Barros NB, Wells RS (1998) Prey and feeding patterns of resident bottlenose dolphins (Tursiops truncatus) in Sarasota Bay, Florida. J Mammal 79:1045-1059

Braun-McNeill J, Goodman MA, Patton BW (2010) Surfacing behavior of loggerhead (Caretta caretta) sea turtles in estuarine and coastal waters of North Carolina. NOAA Tech Memo NMFS-SEFSC-605. NMFS, Beaufort, NC

Burnham KP, Anderson DR (2002) Model selection and multimodel inference: a practical information-theoretic approach, 2nd edn. Springer-Verlag, New York, NY

Byles RA (1988) Behavior and ecology of sea turtles from Chesapeake Bay, Virginia. PhD dissertation, College of William and Mary, Williamsburg, VA

Byrd B, Hohn AA, Munden FH, Lovewell GN, LoPiccolo RE (2008) Effects of commercial fishing regulations on stranding rates of bottlenose dolphins. Fish Bull 106: 72-81

> Byrd B, Hohn AA, Godfrey MH (2011) Emerging fisheries, emerging fishery interaction with sea turtles: a case study of the large-mesh gillnet fishery for flounder in Pamlico Sound, North Carolina, USA. Mar Policy 35: 271-285

Chao LN, Musick JA (1977) Life history, feeding habits, and functional morphology of juvenile sciaenid fishes in the York River estuary. Fish Bull 75:657-702

Cochran WG (1977) Sampling techniques, 3rd edn. Wiley and Sons, New York, NY

Copeland BJ, Gray J (1991) Status and trends of the Albemarle-Pamlico estuaries. Albemarle- Pamlico Estuarine Study Report 90-01. North Carolina Department of Environment and Natural Resources, Raleigh, NC

Daniel, LB (2012) Application for an individual incidental take permit under the Endangered Species Act of 1973. North Carolina Department of Environment and Natural Resources, North Carolina Division of Marine Fisheries, 
Morehead City, NC. Available at http://www.nmfs.noaa. gov/pr/pdfs/permits/ncdmf_seaturtle_itp_application_ updated2013.pdf (accessed 9 Dec 2013)

Duke Law School (2010) Settlement agreement. Duke University, Durham, NC. Available at http://law.duke. edu/sites/default/files/migrated_files/1340204013dl_filenews-pdf-05-13-10SignedSettlementAgreement.pdf (accessed 1 Mar 2013)

Eberhardt LL, Chapman DG, Gilbert JR (1979) A review of marine mammal census methods. Wildl Monogr 63: $1-46$

Epperly SP, Braun J, Chester AJ (1995a) Aerial surveys for sea turtles in inshore waters. Fish Bull 93:254-261

Epperly SP, Braun J, Veishlow A (1995b) Sea turtles in North Carolina waters. Conserv Biol 9:384-394

Epperly SP, Braun-McNeill J, Richards PM (2007) Trends in catch rates of sea turtles in North Carolina, USA. Endang Species Res 3:283-293

Finkbeiner EM, Wallace BP, Moore JE, Lewison RL, Crowder LB, Read AJ (2011) Cumulative estimates of sea turtle bycatch and mortality in USA fisheries between 1990 and 2007. Biol Conserv 144:2719-2727

Gannon DP (2003) Behavioral ecology of an acoustically mediated predator-prey system: bottlenose dolphins and sciaenid fishes. PhD dissertation, Duke University, Durham, NC

Gannon DP, Waples DM (2004) Diets of coastal bottlenose dolphins from the US mid-Atlantic coast differ by habitat. Mar Mamm Sci 20:527-545

Goodman Hall A, Belskis LC (2012) Guide to the aerial identification of sea turtles in the US Atlantic and Gulf of Mexico. NOAA Tech Memo NMFS-SEFSC-633

Grant GS, Malpass H, Beasley J (1996) Leatherback turtle and jellyfish surveys on Topsail Island, North Carolina. In: Keinath JA, Barnard DE, Musick JA, Bell BA (compilers) Proc 15th Annu Workshop Sea Turtle Biol Conserv. NOAA Tech Memo NMFS-SEFSC-387

Hawkes LA, Broderick AC, Coyne MS, Godfrey MH, Godley BJ (2007) Only some like it hot-quantifying the environmental niche of the loggerhead sea turtle. Divers Distrib 13:447-457

Heppell SS, Caswell H, Crowder LB (2000) Life histories and elasticity patterns: perturbation analysis for species with minimal demographic data. Ecology 81: 654-665

Keinath JA (1993) Movements and behavior of wild and head-started sea turtles. PhD dissertation, College of William and Mary, Williamsburg, VA

Keinath JA, Musick JA, Barnard DE (1996) Abundance and distribution of sea turtles off North Carolina. MMS 95-0024. Minerals Management Service, US Department of the Interior, Gulf of Mexico OCS Region, New Orleans, LA

Kenney RD (1990) Bottlenose dolphins off the northeastern United States. In: Leatherwood S, Reeves R (eds) The bottlenose dolphin. Academic Press, New York, NY, p 369-386

Keystone Center (2012) Bottlenose dolphin take reduction team webinar summary report. Provided to the National Marine Fisheries Service, Southeast Regional Office, Keystone, CO

Kolkmeyer T, Guthrie B, Byrd BL, Hohn AA (2009) Report on the alternative platform observer program in North Carolina: January 2007 to May 2009. NOAA Tech Memo NMFS-SEFSC-592. NMFS, Beaufort, NC
Lee DS, Palmer WM (1981) Records of leatherback turtles, Dermochelys coriacea (Linnaeus), and other marine turtles in North Carolina waters. Brimleyana 5:95-106

Lee TN, Atkinson LP, Legeckis R (1981) Observations of a Gulf Stream frontal eddy on the Georgia continental shelf, April 1977. Deep-Sea Res A 28:347-378

> Lewison RL, Crowder LB, Read AJ, Freeman SA (2004) Understanding impacts of fisheries bycatch on marine megafauna. Trends Ecol Evol 19:598-604

Mansfield KL (2006) Sources of mortality, movements and behavior of sea turtles in Virginia. PhD dissertation, College of William and Mary, Williamsburg, VA

> Mansfield KL, Saba VS, Keinath JA, Musick JA (2009) Satellite tracking reveals a dichotomy in migration strategies among juvenile loggerhead turtles in the Northwest Atlantic. Mar Biol 156:2555-2570

> McClellan CM, Read AJ (2007) Complexity and variation in loggerhead sea turtle life history. Biol Lett 3:592-594

McClellan CM, Read AJ (2009) Confronting the gauntlet: understanding incidental capture of green turtles through fine-scale movement studies. Endang Species Res 10:165-179

McClellan CM, Read AJ, Price BA, Cluse WM, Godfrey MH (2009) Using telemetry to mitigate the bycatch of longlived marine vertebrates. Ecol Appl 19:1660-1671

McClellan CM, Read AJ, Cluse WM, Godfrey MH (2011) Conservation in a complex management environment: the by-catch of sea turtles in North Carolina's commercial fisheries. Mar Policy 35:241-248

McCullagh P, Nelder JA (1989) Generalized linear models, 2nd edn. Chapman and Hall, New York, NY

> Moore JE, Wallace BP, Lewison RL, Zydelis R, Cox TM, Crowder LB (2009) A review of marine mammal, sea turtle, and sea bird bycatch in USA fisheries and the role of policy in shaping management. Mar Policy 33:435-451

Morreale SJ, Meylan AB, Sadove SS, Standora AE (1992) Annual occurrence and winter mortality of marine turtles in New York waters. J Herpetol 26:301-308

Murray KT (2009) Characteristics and magnitude of sea turtle bycatch in US mid-Atlantic gillnet gear. Endang Species Res 8:211-224

NCDMF (North Carolina Division of Marine Fisheries) (2005) North Carolina fishery management plan for the southern flounder (Paralichthys lethostigma). NCDMF, Morehead City, NC

NCDMF (North Carolina Division of Marine Fisheries) (2009) Commercial large mesh gill nets. Proclamation M-14-2009. NCDMF, Morehead City, NC. Available at www.ncfisheries.net/procs/procs2K9/M-14-2009.html (accessed 1 Mar 2013)

NCDMF (North Carolina Division of Marine Fisheries) (2011) Commercial gill nets - Pamlico Sound Gill Net Restricted Area (PSGNRA). Proclamation M-31-2011. NCDMF, Morehead City, NC. Available at http://portal. ncdenr.org/web/mf/proclamation-m-31-2011 (accessed 1 Mar 2013)

NCDMF (North Carolina Division of Marine Fisheries) (2013) North Carolina Marine Fisheries Commission rules. NCDMF, Morehead City, NC. Available at http://portal. ncdenr.org/web/mf/rules-and-regulations (accessed 1 Mar 2013)

Nelson DA (1996) Subadult loggerhead sea turtle (Caretta caretta) behavior in St. Mary's entrance channel, Georgia, USA. PhD dissertation, College of William and Mary, Williamsburg, VA 
NMFS (National Marine Fisheries Service) (1996) Sea turtle conservation; restrictions applicable to fishery activities; summer flounder fishery-sea turtle protection area. Fed Regist 61:1846-1848

NMFS (National Marine Fisheries Service) (1999) Sea turtle conservation; restrictions to fishing activities. Fed Regist 64:70196-70198

NMFS (National Marine Fisheries Service) (2001) Endangered Species Act Section 7 consultation. Biological opinion. Authorization of fisheries under Monkfish Fishery Management Plan [Consultation No. F/NEW/2001/ 00546]. NMFS, Northeast Regional Office, Gloucester, MA

NMFS (National Marine Fisheries Service) (2002a) Sea turtle conservation; restrictions to fishing activities. Fed Regist 67:71895-71900

NMFS (National Marine Fisheries Service) (2002b) Sea turtle conservation; activities related to fishing. Fed Regist 67:56931-56934

NMFS (National Marine Fisheries Service) (2006) Taking of marine mammals incidental to commercial fishing operations; bottlenose dolphin take reduction plan regulations; sea turtle conservation; restrictions to fishing activities. Fed Regist 71:24776-24797

NMFS (National Marine Fisheries Service) (2012) List of fisheries for 2012. Fed Regist 76:73912-73953

NOAA (1989a) Comprehensive Large Array-data Stewardship System. NOAA Satellite and Information Service. Available at www.class.noaa.gov/nsaa/products/ welcome (accessed 1 Mar 2013)

NOAA (1989b) Coastwatch Central Operations. NOAA Satellite and Information Service. Available at http://eastcoast. coastwatch.noaa.gov/cw_data_access.php (accessed 1 Mar 2013)

NOAA (1989c) National Geophysical Data Center Satellite and Information Service. Available at www.ngdc.noaa. gov/ngdcinfo/onlineaccess.html

Pacheco AL (1962) Age and growth of spot in lower Chesapeake Bay, with notes on the distribution and abundance of juveniles in the York River System. Chesap Sci 3: 18-28

Pearson JC (1932) Winter trawl fishery of the Virginia and North Carolina coasts. US Bur Fish Invest Rep 10

Pietrafesa LJ, Janowitz GS, Wittman PA (1985) Physical oceanographic processes in the Carolina Capes. In: Atkinson LP, Menzel DW, Bush KS (eds) Oceanography of the southeastern US continental shelf. Coastal and Estuarine Sciences, Vol 2. American Geophysical Union, Washington, DC, p 23-32

R Development Core Team (2007) R: a language and environment for statistical computing. R Foundation for Statistical Computing, Vienna. Available at www.rproject.org (accessed 1 Mar 2013)

Read AJ (2008) The looming crisis: interactions between marine mammals and fisheries. J Mammal 89:541-548

Read AJ, Murray KT (2000) Gross evidence of humaninduced mortality in small cetaceans. NOAA Tech Memo NMFS-OPR-15. NMFS, Silver Spring, MD
Read AJ, Urian K, Wilson B, Waples D (2003) Abundance of bottlenose dolphins in the bays, sounds, and estuaries of North Carolina. Mar Mamm Sci 19:59-73

$>$ Read AJ, Drinker P, Northridge S (2006) Bycatch of marine mammals in US and global fisheries. Conserv Biol 20: 163-169

Roelofs EW, Bumpus DF (1953) The hydrography of Pamlico Sound. Bull Mar Sci Gulf Caribb 3:181-205

Schwartz FJ (1978) Behavioural and tolerance responses to cold water temperatures by three species of sea turtles (Reptilia, Cheloniidae) in North Carolina. Fla Mar Res Publ 33:16-18

Scott MD, Wells RS, Irvine AB (1996) Long-term study of bottlenose dolphins in Florida. IBI Rep 6:73-80

Shoop CR, Kenney RD (1992) Seasonal distributions and abundance of loggerhead and leatherback sea turtles in waters of the northeastern United States. Herpetol Monogr 6:43-67

Spotila JR, O'Connor MP, Paladino F (1997) Thermal biology. In: Lutz PL, Musick JA (eds) The biology of sea turtles. CRC Press, Boca Raton, FL, p 137-163

Steve C, Gearhart J, Borggaard D, Sabo L, Hohn A (2001) Characterization of North Carolina commercial fisheries with occasional interactions with marine mammals. NOAA Tech Memo NMFS-SEFSC-458. NMFS, Beaufort, $\mathrm{NC}$

TEWG (Turtle Expert Working Group) (2009) An assessment of the loggerhead turtle population in the western North Atlantic Ocean. NOAA Tech Memo NMFS-SEFSC-575. NMFS, Miami, FL

The Mathworks Inc. (1994) The MathWorks - MATLAB and Simulink for technical computing. Available at www. mathworks.com (accessed 1 Mar 2013)

Torres LG, McLellan WA, Meagher E, Pabst DA (2005) Seasonal distribution and relative abundance of bottlenose dolphins, Tursiops truncatus, along the US mid-Atlantic Coast. J Cetacean Res Manag 7:153-161

Venables WN, Ripley BD (2002) Modern applied statistics with $\mathrm{S}$, 4th edn. Springer, New York, NY

> Ver Hoef JM, Boveng PL (2007) Quasi-Poisson vs. negative binomial regression: How should we model overdispersed count data? Ecology 88:2766-2772

Waring GT, Josephson E, Maze-Foley K, Rosel PE (2011) US Atlantic and Gulf of Mexico marine mammal stock assessments - 2010. NOAA Tech Memo NMFS-NE-219. NMFS, Woods Hole, MA

Warlen SM (1980) Age and growth of larvae and spawning time of Atlantic croaker in North Carolina. Proc Annu Conf Southeast Assoc Fish Wildl Agencies 34:204-214

Wilk SJ (1979) Biological and fisheries data on weakfish, Cynoscion regalis (Bloch \& Schneider). NOAA Tech Ser Rep 21. NMFS, Sandy Hook Laboratory, Highlands, NJ

Wilson CJ (1997) Estuarine gillnet fishery assessment. In: Assessment of North Carolina commercial fin fisheries, 1994-1996. Completion report for Project 2-IJ-51. North Carolina Department of Environment and Natural Resources, NCDMF, Morehead City, NC, p 6.1-6.5

Submitted: March 11, 2013; Accepted: August 22, 2013
Proofs received from author(s): December 11, 2013
Editorial responsibility: Eric Gilman, Honululu, Hawaii, USA 